\title{
Disrupting the Habitus? Media representations and participant experience of Teach First: an exploratory case study in Wales.
}

\author{
Alex Southern \\ Faculty of Education and Communities, University of Wales Trinity Saint David, \\ Cardiff, Wales
}

The Registry

King Edward VII Avenue

Cardiff

CF10 3NS

a.southern@uwtsd.ac.uk

02920375055 


\title{
Disrupting the Habitus? Media representations and participant experience of Teach First: an exploratory case study in Wales.
}

\begin{abstract}
Teach First is a schools-based route into teaching, where graduates are able to train while employed by 'disadvantaged' schools. Established in 2002, the charity works in partnership with teacher training providers around England and Wales. The first Teach First Cymru cohort began in 2013, at the University of Wales Trinity Saint David (UWTSD). Drawing on the work of Bourdieu, this paper will discuss the potential impact of Teach First Cymru on the teaching habitus, through public and personal articulations of the profession, set within the context of critical debate surrounding the programme. In order to do so, the paper will explore media representations of Teach First and data generated from focus groups and interviews with Teach First Cymru participants and trainees on the Graduate Teacher Programme (GTP) at the same university.
\end{abstract}

Keywords: Teach First; Initial Teacher Education; media representations; Wales

\section{Introduction}

In 2012 Teach First commissioned a progress report, entitled 10 Years of Impact (Hill, 2012). The report traces the organisation's development from its early days as a smallscale intervention tackling educational disadvantage in London schools to a much larger concern, offering an employment-based route into teaching across nine regions in England, and Wales. The publication also outlines the advances the organisation believes it has made towards achieving its Mission, that "no child's educational success is limited by their socio-economic background" in the ten years since its creation (Hill, 2012). The Mission is one with which education practitioners, policy-makers and the wider public would be hard-pressed to disagree, and it is the central strand against which Teach First aims to measure its 'impact' as an organisation, and that of the university graduates who successfully apply to join its ranks. The rhetoric of the 
charity's website and publications, and the language used by Teach First personnel in training sessions, centres on the notion of impact. This impact is located across a range of sites. These sites include the schools and communities where trainees aim to "make a difference' to the attainment of pupils facing educational disadvantage, and in the less tangible discursive space inhabited by policy-makers and governments where the programme aims to demonstrate the fulfilment of its Mission. The Teach First identification and analysis of impact focuses, quite rightly, on ascertaining the extent to which the trainees are able to reduce the relative influence of socio-economic disadvantage on the achievements of their students. It also focuses on ensuring any positive effects are maximised by responding to evaluations of the trainees, schools and pupils, and of the programme itself.

Teach First was established in 2002, after management consultants, McKinsey and Company were employed by London First and Business in the Community on a pro bono basis to investigate how the business sector could help in raising the attainment levels of pupils in London schools (Hutchings et al, 2008). The consultancy report produced by McKinsey and Co. identified that excellent teaching is a significant factor influencing pupils' performance, and that this influence was felt particularly strongly in “challenging" schools (Hutchings et al, 2008, p.2). The consultants proposed the creation of a programme that followed the model of Teach for America, which had been established in 1989, building on the experience of practitioners in the United States to improve London's most disadvantaged schools. After taking advice from academics and teacher trainers, and receiving support from the Institute of Education, Teach First CEO and former McKinsey and Co. employee Brett Wigdortz launched the organisation in 2002 (Wigdortz, 2012). The concept has since spread across the world. In 2007, 
Wigdortz and Teach for America founder, Wendy Kopp, established Teach for All, a global network of organisations that are locally led and coordinated (Exley, 2014c), and which in 2018 has 46 international partner organisations across six continents (www.teachforall.org). The initial, three year contract between Teach First and the Welsh Government began in 2013, and was delivered in partnership with UWTSD. Teach First Cymru aims to recruit graduates to work in secondary schools in the country's most disadvantaged areas. The Leadership Development Programme onto which graduates are accepted, lasts two years, beginning with a six week intensive training course delivered at the University, over the summer. In September, the participants are placed in schools classed as 'disadvantaged' according to the number of pupils eligible for free school meals (eFSM) and the schools' qualification for the Welsh Government's Pupil Deprivation Grant. The participants are employed by the schools and receive training from the University and Teach First to complete a PostGraduate Certificate in Education (PGCE) and achieve Qualified Teacher Status (QTS) in their first year of teaching. QTS is the professional requirement that enables teachers to work in state schools that are maintained by Local Authorities. Teach First participants enter into a contract to remain in their allocated schools for a minimum of two years, which includes the training year, and their first year as a Newly Qualified Teacher - the descriptor given to those teachers who have achieved QTS. A PGCE is a one or two-year course available in England, Wales and Northern Ireland. It provides the training and periods of work experience on school placement that allows graduates to become school teachers. Like Teach First and the GTP, the PGCE is primary or secondary education also results in Qualified Teacher Status - assuming the graduate passes the course. In 2014, the first year of operation in Wales, Teach First Cymru had an allocation of 40 participants, distributed across schools in South Wales. By 
This is an Accepted Manuscript of an article published by Taylor \& Francis in Teachers and Teaching on [5 Feb 2018], available online: http://www.tandfonline.com/10.1080/13540602.2018.1435526

comparison, 186 participants were placed in London schools in 2003, the organisation's first year.

This paper will discuss media representations of Teach First participants, set within the context of critical debate surrounding the programme; compare these publicfacing representations with the opinions, perceptions and personal/professional identities as described by participants from the 2014 cohort in Wales; outline a comparative analysis of the emerging professional identities of Teach First Cymru participants and Graduate Teacher Programme (GTP) trainees studying at the same university in Wales. Finally, the paper builds on these analyses to discuss the relative impact of Teach First Cymru on the teaching habitus, through public and personal articulations of the profession. The term habitus refers to the specific requirements and expectations of a 'teacher' that shape how s/he will perform his/her role. The data was generated over the 2014-2015 academic year, through focus group discussions with GTP (n=6) and Teach First participants (n=4) in December 2014 and June 2015; and individual, semi-structured interviews with each of the research participants $(n=10)$ mid-way through the year-long training programmes. Research participants were drawn from the entire cohort of trainee teachers enrolled in the Teach First $(n=39)$ and GTP $(n=17)$ programmes for the academic year commencing 2014. Participants were invited to volunteer, at a whole-cohort training day, with the aim of generating a random sample who would cooperate with the research in order to avoid non-response. Six volunteers came forward from each cohort, who would form the basis of a year-long exploratory case study. The participants were training in different schools across South, South-East and West Wales. Two volunteers from the Teach First cohort later withdrew from the research, for undisclosed reasons, leaving four case studies for the final data. 
The researcher has no connection to the Teach First or GTP courses, in terms of teaching, course design or programme delivery, at UWTSD or any other university. She did not supervise any of the students, or know any of them personally. Nevertheless, there was a risk that participants may have felt coerced into providing biased responses during focus groups or discussion, due to the researcher's position as employee of the University. This risk was mitigated through verbal and written assurance prior to voluntary, informed consent being granted, that assured participants of their rights to anonymity, confidentiality, and that the research would have no impact on their role as trainee, student or teacher. Participants were given the opportunity to ask questions on this subject before consenting to participate.

The focus group discussions centred on the trainees' views of teaching, why they chose the profession, and this particular training route. The aim was to generate data that would enable the comparative analysis of the trainees' aspirations and perceptions of teaching, and to repeat this line of questioning later in July 2015 to investigate emerging definitions of 'professional identity'. There are limitations to using focus groups in generating reliable data, particularly when the group share the characteristic of being on the same teacher training programme. For example, it can be difficult to ascertain whether opinions are actually shared across the group, or reflective of the rhetoric of the training programme itself. Nevertheless, holding separate focus groups for Teach First and GTP trainees does enable a comparative analysis of discourses used by student teachers across the two training programmes. The semistructured interviews focused on participants' experience of teaching, and the questions asked reflected concepts raised in the public discourse surrounding the Teach First 
programme. An interview guide was written in advance and followed with each participant. The questions included the challenges they faced, how they would overcome them, what 'lessons' they had learned, and what 'qualities' they felt they possessed as teachers. All focus groups and interviews were audio recorded and transcribed to aid recall and analysis.

\section{'Making an Impact'}

Research into the Teach First programme in England has identified a positive impact on pupils' attainment, and attributed this to a range of factors across the Teach First programme. These factors include the rigorous selection criteria, the support networks offered to Teach First participants by both Teach First and the Higher Education Institution providing the training, and the focus on the programme's mission and values (e.g. Allen and Allnutt, 2014; Hutchings et al, 2006; Muijs et al, 2010). The 2011 Ofsted inspection of Teach First judged provision to be 'outstanding' across all four English regions and in all areas of the inspection. In the 2015 Ofsted inspection, the Teach First training was rated 'outstanding' in 41 of the 48 Ofsted categories (Teach First, 2016). Both the 2011 and 2008 Ofsted reports reference the personal 'qualities' of individuals selected by Teach First as contributory factors to this 'success', in particular, the high levels of 'self-efficacy' and the 'professionalism' of the trainees. This argument is echoed by research published by Muijs et al (2010) and was referenced earlier by the study carried out by Hutchings et al (2006). However, further research into the impact of the Teach First programme on evolving teacher identities, has argued a link between government policy agenda and definitions of 'professionalism' that do not always best serve the needs of education (Leaton Gray and 
Whitty, 2010; Smart et al, 2009).

Hutchings et al (2008) found that Teach First trainees saw the programme as more prestigious than the 'traditional' Post-Graduate Certificate in Education (PGCE). The report's authors argue that the participants were encouraged to see themselves as an "elite group", and that the promotion of the Teach First programme to candidates in the 'top' universities was designed to appeal to a sense of personal ambition as well as the more altruistic goal of contributing to overcoming educational disadvantage (Hutchings et al, 2008, p.14). The response from these individuals does not provide sufficient evidence to prove that Teach First is considered in greater standing than other training routes to the wider public, or even to other teachers. However, the response highlights an alternative interpretation of 'exclusivity' that moves away from simply referencing the number of applicants selected, to a more elitist modelling of the profession. CEO of Teach First, Brett Wigdortz, states openly that the organisation aims to attract graduates from what he describes as the "top universities" in Britain (Wigdortz, 2012, p.124). The evidence of Teach First's 'success' in this regard implies a positive, and muchneeded, injection of resources and enthusiasm into what has been described by the previous, Coalition government as a 'failing' system (e.g. Gove, 2013). However, the "high levels of exclusivity" (Wigdortz, 2010, p.127) that have worked to considerably positive effect in marketing and recruitment, do not necessarily translate to the teaching profession as a whole, and the implied hierarchy which exists in the language of its description has opened Teach First up to criticism. Leaton-Gray and Whitty (2010) argue that the impact of Teach First, beyond any consideration of raising educational standards, is to shift teacher professionalism away from specialist knowledge and skills, and towards a more generalised understanding of teaching as a graduate entry 
profession with an emphasis on management skills, such as leadership. Taken from Bourdieu's $(1988 ; 1994 ; 1996)$ theoretical positioning, Leaton-Gray and Whitty apply the term 'habitus' to describe the concept that our actions are "regulated by a set of durable and generative principles" (2010, p.6). In the example of teaching, the habitus describes the specific requirements and expectations of a 'teacher' that impose parameters on the ways and means by which that individual will perform his/her role. Leaton-Gray and Whitty (2010) describe how the specific requirements and expectations of teachers are increasingly controlled by government, thereby shifting the habitus to describe new understandings of the profession, and, by extension, the concept of 'professionalism'. The result is that compliance with government interventions and achievement of government-driven 'standards' is increasingly recognised as a mark of professionalism. Rather than training a new generation of graduates with a long-term commitment to the profession of teaching, the programme is creating a workforce seeking a generic graduate career that is "individually self-serving", and does not contribute to developing the profession as a whole (Leaton-Gray and Whitty, 2010, p.13). There is no reason why the charity should take responsibility for developing the whole teaching workforce, nor for constructing and conveying a collective professional identity. However, the argument raised by Leaton-Gray and Whitty (2010) that the identity of 'Teach First Teacher' may be transitory and actually disrupt rather than promote the profession of teaching is cause for concern.

Stanfield and Cremin (2013) build on the notion of evolving definitions of teacher habitus to suggest that there are now three 'ideal' types of teacher, originally promoted by the Coalition Government. The paper also draws on the concept of elitism with respect to Teach First, and offers a means of exploring the programme and its 
rhetoric beyond the use of the term 'elite' in the marketing materials. The 2010 White Paper and circulating Conservative-driven discourse outline and promote the creation of three distinct types of teacher, which Stanfield and Cremin refer to as the "Elite Graduate", exemplified by the Teach First programme, "High Flyer" and "Ex-Soldier" (Stanfield and Cremin, 2013, p.22). Through a critical language study, the article concludes that these ideals perform dual functions: to legitimate the type of teacher that effectively supports Conservative ideology, and to give these particular identities authority over pupils and the education sector more widely. The argument follows that the 'ideal' teacher types function to import Conservative ideologies into the classroom, and to create and perpetuate practices which enable the transfer and communication of these ideologies. In order for the ideologically sympathetic practices to be accepted within the educational context, the context needs to shift. This is achieved through discourse. For example, specific types of pupil, schools, behaviours become 'challenging', and attainment becomes an issue of pupils not understanding, and teachers not effectively teaching, the 'value' of education. A new type of teacher who is trained to overcome the challenges, and to teach pupils the appropriate values is therefore required to restore order. In the case of the 'Elite Graduate', embodied through the Teach First programme, the context is re-structured so that teaching is a flexible, graduate career choice, requiring two years' commitment before moving into a career in 'leadership'. By remaining at a distance from the teaching profession and identifying with external professions, such as the 'real world' of market-driven industry, the Elite Graduate is able to retain the identity of "valued outsider" (Stanfield and Cremin, 2013, p.32), functioning as a symbol and advocate for the advantages of elite, university education. While this analysis does not consider the motivations or identities of the Teach First trainees on an individual level, the language used by the organisation 
to describe and justify its practices also functions to define the collective identity/habitus of the Teach First Teacher.

\section{Teach First in the Media.}

Nicholas was represented as just such an 'Elite Graduate' in the Tough Young Teachers (2014) documentary broadcast on BBC Three. The series followed six Teach First 'participants' through their Leadership Development Programme over the course of a school year. Five of the participants were in the first, PGCE year, and the sixth was in her second year, working as an NQT. Having attended Harrow and graduated in Engineering from Imperial College, Nicholas was placed in Harefield Academy as a Maths teacher. Harrow is an independent boarding school for boys, age 13-18, that charges around $£ 13,000$ per term, or approximately $£ 40,000$ per school year. As such, Nicholas' school experience would have been rather different to those pupils he taught at Harefield Academy. Throughout the series, Nicholas is represented as having an affinity with teaching and with the pupils, until the end of the year when he struggles to maintain relationships with his class, becomes unsure of his future career choice and ultimately decides to leave for personal reasons. His decision to quit teaching was reasonable enough; his fiancée lived in France and was unable to transfer her studies to the UK. However, it is the way in which Nicholas was represented as 'other' that is of interest here. He already stands out from his pupils due to his accent and Harrow School education, and is described as "posh" by one of the girls in his class. He is also marked as 'different' from his university peers. While discussing their careers over lunch, Nicholas' friends make fun of his choice not to work in the City and repeat their admiration of him for taking a lower salary and working harder than they claim to be 
able. Furthermore, his fiancée laughs openly at his choice of low pay and long hours, when he could be working for her father's firm in France. None of these details are particularly remarkable on their own. However, it is the means by which the documentary establishes these aspects of his personality in contrast to the pupils at Harefield Academy, and situates all of the Teach First 'characters' in opposition to their own pupils, that sets the tone of the programme, and demonstrates the elitism present in the Teach First message.

The analysis of Teach First discourse relayed through marketing materials and some of the programme's trainees carried out by Smart et al (2009) amplifies the issue. The research found that, despite working hard to reduce educational disadvantage, the actions of the trainees on the Teach First scheme actually functioned to reproduce the privilege enjoyed by the middle classes. The trainees all possessed social, cultural and economic capital (from Bourdieu), gained and perpetuated through their own access to education. Attending a 'top' university requires access to 'good' education and/or contacts in the first instance, graduating from that university with a 'good' degree further builds on the capital, and selection onto Teach First underlines possession of social, cultural, economic capital since the participant has been chosen to 'make a difference' to those identified as lacking capital. The language of the organisation's promotional and instructional material, which becomes the discourse of the 'participants' on the Leadership Development Programme, positions the trainees in opposition to the pupils in the schools in which they will teach. For example, the Teach First recruitment brochure states that, "we take outstanding graduates and help them to evolve into dynamic leaders and role models who care deeply about their students, who believe their students can succeed in learning and in life, and who are determined to 
make that success a reality" (Teach First, 2014, p.4). The same document also claims that the programme, "is an increasingly influential movement for social change targeting educational disadvantage by driving up standards and raising aspirations in schools in challenging circumstances" (ibid, p.4). This statement implies the standards and aspirations of 'challenging' schools are low, yet the qualifying criteria for schools to join the programme are socio-economic. Smart et al (2009) argue that the emotive dichotomy established by Teach First, in which the participants make a (positive) difference to the pupils' disadvantaged (negative) school/education/circumstances, work to reinforce a social hierarchy and obscure the role of middle-class privilege in establishing this division. The researchers found that during interview, this language was reinforced by participants (Smart et al, 2009). The Teach First focus on recruiting 'outstanding' graduates, leads to the assumption that they are in some way innately brilliant, and that access to capital has had no effect on their own educational achievement.

In Tough Young Teachers (2014) specific pupils are selected to convey particular narratives and represent the 'types' of working class pupils who attend 'disadvantaged' schools. For example, Caleb, the young Black British boy who has been in a Pupil Referral Unit and is struggling to catch up in time for GCSEs; the working class white boy whose mother has passed away, father is absent and who lives with his sister; the group of Black British girls represented as a clique with whom the teacher must gain rapport in order to teach. The pupils that we as viewers gain access to through interviews are all represented as 'disadvantaged', troubled, un-academic, disruptive/disrupted, largely unsupported, with the exception of Caleb, whose mother we meet, and unmotivated to learn. By contrast, the Teach First participants are 
represented as naive, enthusiastic, driven, modest, hard-working, 'different', academic but perhaps not 'in touch' with the working class surroundings. For example, Chloe, in her second year as a Geography teacher, is informed by some boys in her class that since she's from Clapham, not Croydon like them, she won't understand the issues they have to deal with, won't know about "little black boys getting stabbed up and that". The series establishes binary divisions between success, represented by the Teach First teachers, and failure, represented by the 'struggling' pupils in 'disadvantaged' schools; good and bad teaching (through examples of the Teach First teachers' lessons, in particular between Nicholas and Meryl who is almost constantly observed); and ultimately between the middle class, 'Elite Graduates' and their working class pupils.

This dichotomy is borne out in some of the British popular press, with headlines such as, "Top graduates to teach in disadvantaged primary schools” (The Guardian, 2011) and "Graduates reject lure of City jobs to be teachers in deprived schools" (McVeigh, 2013). Teach First 'participants' are repeatedly referred to as "high-flying", "top graduates" from "leading universities" who are "making a difference" by "giving something back" in "challenging" circumstances to pupils in "disadvantaged" schools (For example, Beadle, 2010; Clare, 2006; Daily Mail Reporter, 2012; Exley, 2014a; Exley, 2014b; Exley, 2014c; Kirkup, 2010; Maddern, 2003; McVeigh, 2013; The Guardian, 2011; Wegg-Prosser, 2002; Woodward, 2003). One reporter chooses the phrase "the Kray's former school" as shorthand, thereby aligning the pupils with two of Britain's most notorious gangland racketeers, imprisoned for murder in the late 1960s (Woodward, 2003). Perhaps the journalist was merely alluding to the school's location in the East End of London, but it is difficult to ignore the implication of criminality. An opinion piece in The Guardian elects to focus on the programme's founder in implying 
the positive impact of Teach First, and aligns Brett Wigdortz, CEO,, with John F. Kennedy, claiming Wigdortz's "aspirations are similar to those which motivated" the US President (Wegg-Prosser, 2002). The Education Editor of The Telegraph takes a more straightforward route in praising the programme and opens his article with the confident proclamation that, "Teach First is an unashamedly elitist intervention in the grey world of comprehensive education" (Clare, 2006). These examples demonstrate the heightened rhetoric that surrounds Teach First, and the dual nature of its representation.

Whether Tough Young Teachers (2014) or reportage in British broadsheet and educational press can be interpreted as an accurate representation of the experiences of Teach First trainees, or as documentary evidence of the 'Elite Graduate' professional identities the scheme exemplifies is not under discussion here. The television programme has been constructed to build a narrative of triumph over adversity, and to increase our understanding of and identification with Teach First. The important point is that, having been circulated through this media representation of Teach First trainees, the 'Elite Graduate' model, whether accurate, carrying social and/or cultural capital, or importing Conservative-driven ideologies, can now be seen to exist within public discourse on the teaching profession. What appears to have been observed over the ten years of 'impact' since Teach First was created, is the development of a specific, exclusive professional identity of 'Teach First Teacher' with signifying 'qualities' that carry symbolic currency in the aim to reduce educational disadvantage. 
This is an Accepted Manuscript of an article published by Taylor \& Francis in Teachers and Teaching on [5 Feb 2018], available online: http://www.tandfonline.com/10.1080/13540602.2018.1435526

\section{The Participants' Reflections on Professional Identity}

The above discussion of the 'Elite Graduates' and 'challenging schools/pupils' dichotomy raises questions regarding the veracity of such constructed representations. The following discussion focuses on whether this dichotomy is reflected in the language used by Teach First Cymru 2014 participants to describe their own experiences, alongside comparators offered by trainees on the GTP. As with Teach First, the GTP trainees spend the year of their initial teacher education programme based in a school. They have to achieve the same Government standards to be awarded with 'Qualified Teacher Status' (QTS) in their teaching practice, which qualifies them to teach in the classroom. However, they do not have to complete the Post-Graduate Certificate in Education (PGCE), which is an essential element of the Teach First training programme.

The word 'challenging' functions euphemistically within the newspaper articles and television programme discussed above, implying a range of problems, difficulties, barriers, negative attributes of the schools and pupils who 'qualify' to receive a Teach First participant as a new member of staff. Amongst other questions, relating to their motivation to teach, expectations and experiences so far, I asked a small focus group $(n=4)$ of the 2014 Teach First cohort what they considered to be their greatest challenge. Two of the four stated that maintaining their own "well-being" was going to be their greatest challenge. Lauren was keen to ensure she worked on establishing a balance between working hard in what she admitted would be a difficult year, and having time to "breathe and time to sleep and time to exercise" in order that she felt able to devote all her energy to delivering good lessons. Richie agreed, explaining that he felt he needed to be able to "fire on all cylinders" regularly, because in his words, "if the 
students are being apathetic they don't want a teacher at the front who is as exhausted as they are, they want someone who is going to be, 'this poem is amazing!', you know, who is full of energy about it".

In follow-up interviews, which took place in the second of the three terms of the academic year, both participants elaborated on their perceptions of the challenges they faced. Lauren's well-being continued to be an issue and, in conversation, it became clear that this was linked to a number of other factors relating to her school experience. She described the frustration she felt at spending so much time planning for lessons, which she did not feel she had sufficient training to complete, and at having to create new resources for every session as previous leadership in the school did not have a culture of sharing materials. Although her department had offered to put additional support in place to help Lauren with the planning, and one colleague in particular had been helpful in practical as well as emotional terms, this had not yet materialised, with the result that Lauren felt she was alone in dealing with it. During interview, Lauren did refer to one of her classes as "challenging". However, rather than describing the pupils themselves in these terms, she believed their behaviour - causing "a lot of trouble" - could be explained by the circumstances in which the school had placed them. The class was the "bottom set" and large, with 28 pupils. Without any additional support in the classroom from a Teaching Assistant or one-to-one support for the child with a learning difficulty, Lauren identified the challenge as insufficient time to devote to each individual pupil. She described this as a failing of the school, in not providing enough support for these young people, but conceded that many of the decisions behind this were historical or beyond the control of staff who were themselves stretched to capacity. 
During interview, Richie was buoyant, having just delivered a lesson he felt had gone particularly well, and was less concerned about the challenge of maintaining his own well-being than he had been during the focus group discussion. Instead, he focused on the sheer volume of new things that he was required to learn. While he was confident that he could achieve the requisite level of knowledge and skills, he described it as an ongoing process and how, in the beginning, he wasn't even sure of the questions he needed to ask in order to progress. However, Richie also described finding the "emotional rollercoaster" of teaching more difficult than he expected, and referred again to the need to keep his own energy levels up to ensure he could deliver engaging lessons.

Hannah's response in the focus group had been slightly different to Lauren and Richie. The challenge, Hannah believed then, lay in having the confidence to express her ideas and assert her own presence with colleagues, "not in the classroom, but outside the classroom, around the school ... confidence in the corridors". Two months later, during interview, Hannah reflected on her first term of teaching in secondary school. The greatest challenge for Hannah had been identifying effective strategies that would enable her classes to progress as she would hope, particularly with respect to written literacy. The pupils in her English classes were able to grasp sometimes complex theoretical concepts, and discuss these at significant depth, but were not able to translate this into written work that would demonstrate their understanding of the texts. The challenge lay in supporting these pupils, but more than that, it was the pressure of needing to ensure she was rigorous in monitoring how much progress her pupils were making, in particular the year 10 pupils whose GCSE grades were at stake. The levels 
and standards these pupils needed to achieve within the time available was daunting and required considerable focus. The way in which Hannah described this challenge made clear her belief that achieving the required levels (and a C at GCSE) was her responsibility. In order for her pupils to progress, Hannah would need to teach them how.

Hannah's articulation of her challenges and approach to dealing with them was given further attention by another of her peers. During the focus group, Lewis was the last to contribute to the discussion of the challenges they anticipated. He had not offered his own 'challenge' in response to the question and instead responded to Hannah's concerns regarding confidence "in the corridors". Lewis remarked,

"But that's partly what, you know, self-leadership is about is to have the confidence to say, 'right, I am a member of staff in this school, I am a teacher in this school, and to, kind of, take ownership and responsibility over everything that you possibly can. So that, 'these are my kids, this is my classroom, this is my department, this is my corridor' you know? And to kind of buy in to that wider responsibility of the role."

Lewis' contribution to the discussion is noteworthy because he chose to skip this question, and move on to explain his strategies for dealing with any challenges. This implies either he did not anticipate meeting any challenges, or perhaps that he was convinced he would be able to overcome any difficulties so didn't see them as significant.

The trainees on the GTP anticipated the workload to be one of the greatest challenges, in particular the amount of paperwork. Teamwork was also a concern to one of the GTP trainees, while using ICT effectively was clearly somewhat daunting to another. As a group, the GTP trainees also discussed the need to balance motivating the 
pupils to learn through fun activities, with ensuring that targets were met. The challenges raised by the GTP cohort were similar to those discussed by the Teach First participants, particularly in terms of workload and targets. However, all of the challenges that the GTP group envisaged were external to the trainees, whereas the Teach First participants focused on challenges that stemmed from their own development as teachers. It seemed that the Teach First group were either more conscious of ensuring they achieved to their potential, or more confident in expressing these concerns. This difference in expression is only marginal, and could be attributed to the greater pressure felt by the Teach First participants because of the relative importance placed on levels within the education system. The Teach First group were all teaching in secondary schools, and were mainly placed in classes that were on the C/D border at GCSE level, whereas the GTP group were all training within primary settings. This had not been the intended design of the groups, but a result of voluntary participation in the research. The volunteers from the GTP programme all came from primary schools, and Teach First Cymru does not yet offer a primary route. Nevertheless, the split between external and 'internal' forces became more apparent when the trainees from each of the groups began to discuss their strategies for overcoming the challenges of teacher training.

The GTP focus group spoke collaboratively about how they would overcome the potential difficulties they either envisaged facing, or had experienced so far. The strategies ranged from the practical, such as being organised and prioritising workload continually, to the more philosophical approach of knowing one's own strengths and weaknesses. However, rather than demonstrating a schism between the process of training to teach, and the intellectual pursuit of understanding this learning, what 
became apparent during the conversation, was the crossover between these two schools of thought. The trainees discussed the importance of experience in overcoming the challenges they faced, and the value of working with experienced colleagues to learn the skills and techniques that would enable them to become effective teachers. One of the group added that building good relationships with one's colleagues was also an important element of professionalism. This discussion amongst the group demonstrated a patient understanding of the training process, despite admitting that they were under considerable pressure, and their conversations were light-hearted, peppered with humour and self-effacing anecdotes or comments. The Teach First group were equally good humoured in discussing their teaching experience, and the group's enthusiasm for the profession was made clear throughout the conversation. However, the responses from the group regarding their strategies for overcoming the challenges they had identified, differed significantly from the GTP trainees.

The 'solution' to overcoming challenge that Lewis offered Hannah referred to 'self-leadership'; a term which derives from the Teach First Values. These are defined as Leadership, Excellence, Collaboration, Integrity and Commitment, and Leadership is itself broken down further into distinct elements that describe the aims of the organisation's Leadership Development Programme (www.teachfirst.org). One of these elements, Leading Self, covers, as Lewis outlined, the responsibility that each 'participant' should take for his/her own development, as well as the impact s/he makes in the classroom. The rest of the group also revealed strategies for overcoming challenges that referenced the Teach First Values. These included "reflection", "honesty", and "taking responsibility". One Teach First participant at interview explained how she was overcoming the difficulties of having a high workload and 
limited experience by "sheer willpower", while another described looking back at her notes from Summer Institute for ideas that would help in development of behaviour management skills. These responses demonstrate the difference between the selfreliance of the Teach First participants, and the more collaborative approach to the training process that the GTPs described in their focus group, and at subsequent interviews, such as working with "experienced colleagues", being organised and prioritising, responding to feedback, and gaining experience over time, as outlined above. Given the relatively small scale, the data generated through this study clearly cannot be taken as generalised statements about the Teach First and GTP programmes or their trainees. However, it does raise some interesting questions about the difference between these postgraduate routes into the teaching profession that respond to representations of Teach First circulated in mainstream media.

\section{Conclusion}

Returning to Stanfield and Cremin (2013), there are some indications of the 'Elite Graduate' in the discourse of the Teach First participants. The language the participants use to describe their experiences, particularly the focus on self, strongly reflects the Teach First rhetoric, used for marketing and recruitment purposes. However, the way in which these trainees describe their own emerging identities and current practice does not simply reflect the outstanding/challenging dichotomy, evident in media representations of the programme. We cannot tell from this small-scale research whether these trainees were attracted to the programme because its mission and values reflect their own, or if the Teach First programme encourages them to adopt this stance. However, there is some suggestion from the data generated through this study that the 
participants are using the language of Teach First against itself. During the second focus group discussions, the participants engaged in the following exchange:

Lauren: It's really hard to talk about teaching without being really cheesy isn't it?

It's really hard to talk about it, without being like,

Hannah: Trained into using all them buzzwords isn't it?

Lauren: Yeah, it's all rainbows and butterflies and impact!

Hannah: In the QTS standards, if I keep using 'impact' in the standards, I must get full marks!

Returning to the argument raised by Leaton-Gray and Whitty (2010), there is little evidence in the research data that can either support or refute the claim that Teach First Cymru is disrupting the habitus. In Wales, there are three centres for teacher education, established according to geographical remit. Each Centre has a quota for Secondary PGCE recruitment. This is not a closed system - teachers will undoubtedly join the workforce from outside of the country's borders, and others will leave on achieving QTS. However, the figures give some indication of the numbers of postgraduate students engaged in teacher training programmes year on year. For the 2014-2015 academic year, the quotas for each of the Centres were as follows: North and Mid-Wales Centre of Teacher Education $=257$, South East Wales Centre of Teach Education $=351$, South West Centre of Teacher Education $=272$, giving a total of 880 PGCE Secondary trainees. Meanwhile, Teach First had a quota of 40 participants in the same year. Of course, these figures do not indicate the total number of teachers entering the workforce, or even the total number completing the training programmes.

Nevertheless, the difference in numbers is significant. In 2014-15 academic year, there 
were approx. 22 PGCE Secondary trainees for every Teach First 'participant' in Wales. These small numbers suggest that Teach First Cymru is unlikely to have changed the habitus significantly. However, the Teach First identity is defined external to the participants, as Hutchings et al (2006) acknowledge. The disruption that Leaton-Gray and Whitty (2010) identify refers to the Teach First Brand, rather than any individual enrolled on the programme. Given the rise of Teach First programmes globally, and the strength of the circulating discourse, I would argue that further investigation into the 'impact' of Teach First on the teaching habitus would be beneficial to the profession. 


\section{Appendix}

\section{Interview Guide}

- How was your first term of full time teaching?

○ Was that what you expected?

$\circ$ What have been the highlights?

- What has been your biggest challenge?

○ What have you found to be the most effective strategies/approaches to overcoming this challenge?

- How did you develop these strategies?

- What do you hope to achieve this term?

○ How are you progressing?

- Can you give me an example?

- What do you consider to be your best quality as a teacher?

$\circ$ Why is it important to you?

- What do you want to improve upon?

- And how will you go about doing this?

- How do you think you've changed since September?

- Who or what has motivated that change?

- What is the most valuable lesson you've learned?

○ From whom/what? 


\section{References}

Allen, R. and Allnutt, J. (2013) Matched panel data estimates of the impact of Teach First on school and departmental performance, DoQSS working paper No. 13/11 [online]. Available at: http://repec.ioe.ac.uk/REPEc/pdf/qsswp1311.pdf [Accessed 3 June 2014].

Beadle, P. (2010) Children will lose out under new education policies. The Guardian. 10 August [online]. Available at: http://www.theguardian.com/education/2010/aug/10/education-policiesmisguided [Accessed 5 November 2015].

Bourdieu, P. (1988) [1984]. Homo academicus, P. Collier (trans.). Cambridge: Polity. Originally published as Homo academicus (Paris: Les Editions de Minuit).

Bourdieu, P., Passeron, J-C., and de Saint Martin, M. (1994) [1965] academic Discourse. R. Teese (trans.). Cambridge: Polity. Originally published as Rapport péedagogique et communication (The Hague: Mouton).

Bourdieu, P. (1996) [1989] the State Nobility. Elite Schools in the field of Power, L.C. Clough (trans.). Cambridge: Polity. Originally published as La noblesse d'état. Grandes écoles et spirit de corps (Paris: Les Editions de Minuit).

Clare, J. (2006) 'Teach First is a brilliant idea: absolutely everyone wins'. The Telegraph. 4 March [online]. Available at: http://www.telegraph.co.uk/news/uknews/1512041/Teach-First-is-a-brilliantidea-absolutely-everyone-wins.html [Accessed 5 November 2015].

Daily Mail Reporter (2012) 2,000 elite young teachers are parachuted in to tackle Britain's toughest schools. Mail Online. 24 November [online]. Available at: http://www.dailymail.co.uk/news/article-2237877/2-000-elite-young-teachers- 
This is an Accepted Manuscript of an article published by Taylor \& Francis in Teachers and Teaching on [5 Feb 2018], available online: http://www.tandfonline.com/10.1080/13540602.2018.1435526

parachuted-tackle-Britains-toughest-schools.html\#ixzz3qzUgwyBQ [Accessed 9 November 2015].

Exley, S. (2014a) Bright Lights and Hard Truth: This is Teach First. TES. 15 August [online]. Available at: https://www.tes.com/article.aspx?storycode $=6439811$ [Accessed 5 November 2015].

Exley, S. (2014b) Teach First trebles its presence in early years sector. TES. 7 April [online]. Available at: https://www.tes.com/news/school-news/breakingnews/teach-first-trebles-its-presence-early-years-sector [Accessed 5 November 2015].

Exley, S. (2014c) The unstoppable rise of Teach For All. TES. 3 January [online]. Available at: https://www.tes.com/article.aspx?storyCode $=6387560$ [Accessed 5 November 2015].

Gove, M. (2013) What Does it Mean to be an Educated Person? [online]. Available at: https://www.gov.uk/government/speeches/what-does-it-mean-to-be-aneducated-person [Accessed 29 September 2014].

Hill, R. (2012) Teach First. 10 Years of Impact [online]. Available at: http://www.teachfirst.org.uk/sites/default/files/press/pdf/TF_ImpactReport_2012 35835_1728.pdf [Accessed 3 June 2014].

Hutchings, M., Maylor, U., Mendick, H., Menter, I. and Smart, S. (2006) An evaluation of innovative approaches to teacher training on the Teach First programme: Final report to the Training and Development Agency for Schools. London: Teaching and Development Agency [online]. Available at: https://metranet.londonmet.ac.uk/fms/MRSite/Research/ipse/FINAL\%20Report \%20Teach\%20First\%20July06.pdf [Accessed 3 June 2014]. 
This is an Accepted Manuscript of an article published by Taylor \& Francis in Teachers and Teaching on [5 Feb 2018], available online: http://www.tandfonline.com/10.1080/13540602.2018.1435526

Kirkup, J. (2010) More top graduates to teach in tough schools. The Telegraph. 5 July [online]. Available at: http://www.telegraph.co.uk/education/educationnews/7871417/More-topgraduates-to-teach-in-tough-schools.html [Accessed 5 November 2015].

Leaton Gray, S. and Whitty, G. (2010) Social trajectories or disrupted identities? Changing and competing models of teacher professionalism under New Labour. Cambridge Journal of Education, 40(1), 5-23.

Maddern, K. (2009) A class of their own? The rise and rise of Teach First graduates. TES. 28 August [online]. Available at: https://www.tes.com/article.aspx?storycode $=6021552$ [Accessed 5 November 2015].

Maton, K. (2012) Habitus. In: Grenfell, M. (Ed.) Pierre Bourdieu Key Concepts Second Edition. London: Routledge, pp. 48-64.

McVeigh, T. (2013) Graduates reject lure of city jobs to be teachers in deprived schools. The Guardian. 20 July [online]. Available at: http://www.theguardian.com/education/2013/jul/20/graduates-teach-deprivedschools [Accessed 5 November 2015].

Muijs, D. Chapman, C. Collins, A. Armstrong, P. (2010) Maximum Impact Evaluation. The impact of Teach First teachers in schools. An evaluation funded by the Maximum Impact Programme for Teach First. Final Report [online]. Available at: http://teachfirstnz.org/images/uploads/Documents/Manchester_evaluation_of_T each_First_2010.pdf [Accessed 3 June 2014].

Ofsted (2008) Rising to the challenge: a review of the Teach First initial teacher training programme [online]. Available at: 
This is an Accepted Manuscript of an article published by Taylor \& Francis in Teachers and Teaching on [5 Feb 2018], available online: http://www.tandfonline.com/10.1080/13540602.2018.1435526

http://www.ofsted.gov.uk/resources/rising-challenge-review-of-teach-firstinitial-teacher-training-programme [Accessed 10 June 2014].

Ofsted (2011) Teach First Initial Teacher Education inspection report [online].

Available at:

http://www.ofsted.gov.uk/filedownloading/?id=1720861\&type=1\&refer=1

[Accessed 3 June 2014].

Smart, S., Hutchings, M., Maylor, U., Mendick, H. \& Menter, I. (2009): Processes of middle-class reproduction in a graduate employment scheme. Journal of Education and Work, 22:1, 35-53.

Stanfield, J., \& Cremin, H. (2013). Importing control in initial teacher training: Theorizing the construction of specific habitus in recent proposals for induction into teaching. Journal of Education Policy, 28(1), 21-37.

Teach First (2014) The single most important thing you will do [online]. Available at: http://viewer.zmags.com/publication/b59b956f\#/b59b956f/1 [Accessed 20 June 2014].

Teach First (2016) Our Training is Rated Outstanding by Ofsted [online]. Available at: https://www.teachfirst.org.uk/news/our-training-rated-outstanding-ofsted [Accessed: 9 May 2017].

The Guardian (2011) Top graduates to teach in disadvantaged primary schools. The Guardian. 30 March [online]. Available at: http://www.theguardian.com/education/2011/mar/30/teach-first-goes-intoprimary-schools [Accessed 5 November 2015].

Tough Young Teachers (2014) Episodes 1-6 (broadcast dates 9 January 2014; 16 January 2014; 23 January 2014; 30 January 2014; 6 February 2014; 13 February 2014) [television programme]. London: Victory Television/BBC/Teach First. 
This is an Accepted Manuscript of an article published by Taylor \& Francis in Teachers and Teaching on [5 Feb 2018], available online: http://www.tandfonline.com/10.1080/13540602.2018.1435526

Wegg-Prosser, B. (2002) Teach for the skies. The Guardian. 10 July [online]. Available at: http://www.theguardian.com/education/2002/jul/10/highereducation.uk [Accessed 5 November 2015].

Wigdortz, B. (2012) Success Against the Odds. Five lessons in how to achieve the impossible: the story of Teach First. London: Short Books.

Woodward, W. (2003) Quick fix. The Guardian. 29 July [online]. Available at: http://www.theguardian.com/education/2003/jul/29/teachertraining.schools [Accessed 5 November 2015]. 